\title{
Türkiye'nin Demokratikleşme Sürecinde Bürokrasinin Rolü:Tek-Parti Dönemi ve Çok-Partili Sisteme Geçiş ${ }^{*}$
}

Harun Kınlmaz **

\begin{abstract}
O̊z
Bu çalışmanın amacı demokratikleşme sürecinde bürokrasinin rolü, işlevi ve tutumunu incelemektir. Bu kapsamda Türkiye'de cumhuriyetin ilanından çok-partili hayata geçişe kadar demokratikleşme sürecinin incelendiği bu tarihsel araştırmada, bürokrasi ve demokrasi ilişkisi kuramsal olarak kısaca ele alındıktan sonra Türk siyasi hayatında önemli bir yeri olan bürokratik yönetim geleneğinin oluşumuna değinilmiştir. Daha sonra, tek-parti döneminde demokratikleşme sürecinde bürokrasinin rolü ve çok-partili hayata geçişle birlikte bu süreçte yaşanan değişim incelenmiştir. Sonuç olarak, bürokrasi ve demokrasi arasında bir ikilem bulunduğu, bürokrasinin demokratikleşme sürecini olumsuz yönde etkilediği, tek-parti döneminde bürokrasinin daha etkin olduğu, çok-partili hayata geçişle birlikte nispeten bürokrasinin gücünün azaldığı, ancak bürokratik vesayet geleneğinin günümüze kadar etkisini sürdürdügü ve bu durumun demokratikleşme sürecine zarar verdiği görülmüştür.
\end{abstract}

\section{Anahtar Kelimeler}

Bürokrasi, demokratikleşme, Türkiye, tek-parti dönemi, çok-partili sistem.

\footnotetext{
Geliş Tarihi: 02 Ağustos 2017 - Kabul Tarihi: 15 Ağustos 2017

Bu makaleyi şu şekilde kaynak gösterebilirsiniz:

Kırılmaz, Harun (2020). “Türkiye’nin Demokratikleşme Sürecinde Bürokrasinin Rolü: Tek-Parti Dönemi ve Çok-Partili Sisteme Geçiş”. bilig - Türk Dünyası Sosyal Bilimler Dergisi 92: 1-28.

** Doç. Dr. Sakarya Üniversitesi, İşletme Fakültesi, Sağlık Yönetimi Bölümü - Sakarya/Türkiye

ORCID ID: orcid.org/0000-0001-6055-6826

hkirilmaz@sakarya.edu.tr
} 


\section{Giriş}

En genel ve basit tanımıyla "halk yönetimi" demek olan demokraside siyasal iktidarın meşruiyet kaynağının halk iradesi olması ve siyasal kararların halkın isteklerine uygun olmasının yanı sıra belli başlı temel niteliklerin varlığının gerekliliği de tartışmasız kabul edilmektedir. Siyasal iktidarın özgür, adil ve düzenli genel seçimlerle oluşması, farklı toplumsal çıkar ve görüşleri temsil eden siyasi partilerin olması, farklı toplum kesimlerini temsil eden ve siyasal katılımı kolaylaştıran dernekler ve kitle örgütleri, ekonomik koşulların uygunluğu ve seçilmişlerin üstünlüğü demokrasinin temel niteliklerinin başında gelmektedir.

Demokrasinin temel nitelikleriyle uyumlu olarak seçimleri, siyasi partileri, hükümet sistemlerini, yerelleşmeyi, açıklığı ve sivil toplumu demokratikleşmenin göstergeleri arasında sayabiliriz. Bu unsurlar tek tek veya bir bütün olarak demokratikleşmenin sağlanması ve demokrasinin gelişimi açısından belirleyici olmaktadır. Demokratikleşmenin unsurlarından biri de bürokrasidir ve bu çalışmanın amacı demokratikleşme sürecinde bürokrasinin rolü, işlevi ve tutumunu incelemektir. Dolayısıyla çalışma Türkiye’de çok-partili hayata geçiş döneminde (1945-1960) bürokrasi ve demokrasi ilişkisine yoğunlaşmaktadır.

Burada vurgulanması gereken husus; demokrasi-bürokrasi karşıtlığı noktasına odaklanmak ve konuyu bu çerçevede ele almak yerine, siyasal sistem içinde bürokrasinin oluşumu, yapılanması, hareket tarzı ve uygulamalarının demokratikleşme sürecine etkilerini ortaya koyabilmek daha önemlidir. Kuşkusuz, "bürokrasi demokratikleşmeye engeldir" veya "bürokrasi demokratikleşmenin gereklilikleri arasındadır” önermeleri yerine; genel olarak demokratikleşme süreci içerisinde bürokrasinin rolünün ortaya konabilmesi amaçlanmıştır.

Bu amaçla, çalışmada öncelikle bürokrasi ve demokrasi ilişkisi kuramsal olarak kısaca ele alındıktan sonra Türk siyasi hayatında önemli bir yeri olan bürokratik yönetim geleneğinin oluşumuna değinilmiştir. Daha sonra Türkiye'de demokratikleşme süreci ve Cumhuriyet döneminde demokratikleşme çabaları üzerinde durulmuştur. Son olarak, demokratikleşme sürecinde bürokrasinin rolü ve çok-partili hayata geçişle birlikte yaşanan değişim incelenmiştir. 


\section{Bürokrasi-Demokrasi İlişkisi}

Bürokrasi ve demokrasi kavramları, literatürde bir toplumun yönetimini sağlayan temel yaklaşımlar olarak kabul edilmektedir. Bürokrasinin kamu programlarının etkili bir şekilde uygulanması için gerekli olduğu düşünülse de, vatandaşların istek ve taleplerine büyük oranda kayıtsız olarak kavramsallaştırılmaktadır. Öte yandan demokrasinin vatandaşların istek ve taleplerine duyarlı olduğu ve bu durumun kamu tercihlerine olumlu yönde yansıdığı varsayılmaktadır (Peters 2010: 209). Bürokrasi ve demokrasi oldukça eski ve köklü bir geçmişe sahiptir ve hem teoride hem de pratikte birçok değişim ve dönüşüm geçirmiştir. Demokratik devletler kendi idari örgütlenmelerini bürokrasinin ideal tipine yakın oluşturduklarından, bu modelin benimsenme nedeninin, rasyonel ve etkin olması, yani yöneticiler ve vatandaşlara hizmet etme noktasındaki işlevselliği olduğu ileri sürülebilir (Dreyfus 2014: 18).

Weber'e göre temel bir örgütlenme biçimi olan bürokrasi, modern toplumun ihtiyaçlarına cevap veren bir örgüt tipinin temel özelliklerini tanımlayan, ileri düzeyde rasyonel, kişisellikten arındırılmış, kuralları ve yasaları esas alan bir örgüt modelidir. Weber'e göre bürokrasi, en yüksek verimlilik derecesine ulaşmayı sağlayan ve insanlar üzerinde otorite kurmanın en rasyonel yoludur. Bürokrasi, yasal-rasyonel otoriteyi ve bu otoritenin diğer otorite biçimleri üzerindeki hâkimiyetini ifade eder. Weber bürokrasiyi "bir kez kurulduktan sonra yok edilmesi en zor kurumlardan biri” olarak görür (2004: 200). Weber'e göre bürokrasinin sahip olduğu temel karakteristikleri şahsî konumunun güvenliği ile ilgilenen tüm çıkar sahiplerince desteklenen bir resmiyet ve bürokratların görevlerini, kendilerine bağımlı olanların refahı açısından köklü bir biçimde faydacı anlayışla yapma eğilimi başlıkları altında toplamak mümkündür (2005: 54).

Literatürde demokrasi temel olarak iki farklı anlamda kullanılmakta ve bu çerçevede normatif ve ampirik demokrasi teorisinden bahsedilmektedir (Sartori 1993: 55-56). Normatif demokrasi teorisi, demokrasiyi sözlük anlamından hareketle Abraham Lincoln’ün ifadesiyle "halkın, halk tarafından, halk için yönetimi” olarak tanımlanmaktadır. Ampirik demokrasi teorisi ise ideal anlamda demokrasi yerine, var olan demokrasiyi, demokratik olarak kabul edilen rejimlerin ortak özelliklerini ortaya koymaya çalışmaktadır 
(Lijphart 1986: 1). Gerçek anlamda bir demokrasiden söz edebilmek için vatandaşların iradesini temsil eden seçilmişlere, özgür, adil ve düzenli seçimlere, ifade özgürlüğüne, alternatif bilgi kaynaklarına, siyasi partilere ve sivil toplum kuruluşlarına, vatandaşların sürece dâhil edilmesine gereksinim bulunmaktadır (Dahl 2001: 89-90).

Weber'in demokrasi ve bürokrasi ilişkisini temellendirme biçimi, Kıta Avrupası ve Anglo-Amerikan bakış açısına göre farklılık arz etmektedir. Nitekim bu iki yaklaşım arasında "rasyonellik" yorumu açısından farklılıklar bulunmaktadır. Bu farklılığın en temel özelliği ise, rasyonelliğin Anglo-Amerikan yaklaşımında görgül, Kıta Avrupası yaklaşımında ise mantıksal düzlemde inşa edilmesidir. Bundan dolayı Anglo-Amerikan yaklaşımında işletmecilik / piyasacı ilkeler daha fazla öne çıkmış ve bu anlamda uygulamaya yönelik bir karakter edinmiştir. Buna karşılık Kıta Avrupası yaklaşımında, bilginin üretim süreci bağlamında rasyonellik mantıksal bir çıkarım olarak ele alınmıştır (Akbulut 2005: 66-67).

Bürokrasi, siyasal sistem tarafından belirlenen karar ve kuralları uygulayan, kamu hizmetlerini yerine getiren kurumların örgütlenme biçimini ifade etmektedir (Dursun 2006: 307). Bürokrasi, hükümet etme işinin memurların elinde olduğu yönetim biçimi olarak da tanımlanır. Otoritenin atanmış memurların elinde olduğu ve dolayısıyla vatandaşların yönetime katılma, karar alma ve uygulama süreçlerinden dışlandığı bir yönetim biçimi anlamında kullanılmaktadır (Eryılmaz 2010: 14-15). Bu çerçevede siyasal hareketliliğin, ekonomik gelişmenin, ekonomik ve toplumsal sürece yoğun devlet müdahalelerinin sonucu olarak klasik demokrasi kuramlarından ortaya çıkan modern demokrasi kuramlarına göre (Schmidt 2002: 113-116); bürokrasiyi siyasal iktidar tarafindan belirlenen politikaları objektif bir şekilde uygulayan, siyasal otoriteye bağlı bir yapı olarak tanımlanmak mümkündür (Dursun 2006: 323).

Devlet idaresi anlamında bürokrasi, daha çok memurlar tabakasını ve memurların hâkimiyetini ifade etmek için kullanılmaktadır. Bürokratik devletten kastedilen, idari karar verme yetkisini meslekten yetişme bir memurlar topluluğuna tanıyan sistemdir. Böyle bir yapılanmada, bürokrasinin sıkı bir hiyerarşik çerçevede toplandığı ve siyasi iktidarın otoritesini imtiyazlı bir memurlar zümresiyle paylaşmakta olduğu gözlemlenmektedir. Bu çalışma- 
da bürokrasiden söz edildiğinde kamu yönetimi birimleri içinde yer alan bütün görevliler kastedilmemekte, daha çok kamu politikasını tayin eden ve yöneten kesim anlatılmaktadır.

Bürokrasinin iktidarın her türlü talebine yanıt vermesinin demokratik ilkeler açısından olumlu bir durum olduğunu kabul etmek gerekir. Bürokrasinin kendi kurumsal kültürünün olması, seçilmişlerin isteklerine direnebilmesi, demokrasi açısından bir eksikliktir (Demir 2011: 81). Bürokrasi ile demokrasi arasındaki gerilim, seçilmişler ile atanmışlar arasındaki ilişkinin niteliğinden doğmaktadır. Siyasal kararların uygulayıcısı konumunda bulunan bürokrasinin siyasallaşmayacağını söylemek zordur (Eryiğit ve Yörükoğlu 2012: 5). Bürokrasinin misyonu siyasal otoritenin aldığı kararları uygulama, siyasal karar alma sürecine katılma veya hem karar alma, hem de uygulamada etkin olma noktalarının birinde toplanmaktadır. Siyasal otoritenin aldığı kararları uygulama noktasına yaklaştığı ölçüde demokratikleşmeye olumlu yönde katkı sağladığı, siyasal karar alma sürecine katılma noktasına yaklaştı̆̆ı ölçüde ise olumsuz etkide bulunduğunu söyleyebiliriz.

Demokrasi, güçlü bir merkezî devletle değil, halkın katılım olanaklarını genişleten yaygın bir ademi merkeziyetçilikle, dolayısıyla daha az bürokratik yapıyla daha tutarlıdır. Bu açıdan, demokrasinin çevreden merkeze doğru gelen etkilerinin artması ölçüsünde adıyla tutarlı bir nitelik kazanacağını söylemek mümkündür (Köker 2005: 224-225).

Memurlar tarafından yönetim anlamında bürokrasi, demokrasinin karşısında yer almaktadır. Bu bakımdan demokrasinin gerekleri ile bürokrasinin gerekleri birbirinden farklılık arz etmektedir. Demokrasi eşitlik, katılım, özgürlük, çoğulculuk, açıklık, halkın tercihleri ve seçimlere dayanırken; bürokrasi hiyerarşi, emir-komuta, uzmanlık, gizlilik, gayrişahsîlik ve görevde sürekliliğe dayanmaktadır (Öztürk 2003: 46-47). Bu temel dayanaklardan yola çıkarak bürokrasinin demokrasi açısından bazı olumsuzlukları bünyesinde taşıdığı düşünülmekle birlikte (Eryılmaz 2010: 108-110), demokratik toplumlarda olumlu ve gerekli birtakım fonksiyonları da yürüttüğü kabul edilmektedir (Eryllmaz 2010: 110-112).

Bürokrasi ve demokrasinin başta "eşitlik" olmak üzere birçok konuda farklı gereklilikleri bulunmakla birlikte, bürokratik bir yapılanma olmadan de- 
mokratikleşmenin tam anlamıyla sağlanamayacağı görüşü de öne sürülmektedir (Öztürk 2003: 48). Diğer bir ifadeyle, demokrasinin kanunun üstünlüğü esasına dayandığı göz önüne alınarak bürokrasinin demokratik esas ve usullerle bağdaştı̆̆ (Mises 2000: 38); ayrıca, iki kavramı birbirinin karşıtı olarak değerlendirmemek gerektiği ve bürokrasinin kendisinin değil, uygulamalarının eleştiriye açık olduğunu söylemek mümkündür (Mises 2000: 40-41).

Bürokrasi ve demokrasi arasındaki ilişkiyi destekleyen Oktay (1997: 39-42), bürokratikleşmenin nedenlerinden birinin de demokratikleşme olduğunu ifade etmektedir. Aynı zamanda demokratikleşmenin bürokratik örgütleri güçlendirdiği tespitine de yer vermektedir. Dolayısıyla, bürokrasi ve demokrasi arasında doğrudan bir ilişki olduğunu söylemek mümkündür.

Weber, bürokrasi ile demokrasi arasında gerilim ve kavga olduğunu, bu kavganın bürokrasi ve demokrasinin doğasından kaynaklandığını belirtmektedir (Öztürk 2003: 36). Bürokrasi bir yandan modern toplumlar için teknik bakımdan üstün ve gerekli görülürken diğer açıdan, bürokrasinin demokratikleşme ve çoğunluğun söz hakkı ilkesine tezat teşkil ettiği ifade edilmektedir (Öztürk 2003: 42). Buradan hareketle, Weber'e göre modern devletin karşılaştığı en büyük sorunlardan biri, otoriteyi paylaşmada siyasetçiler ve bürokratlar arasında denge sağlamaktır. Bu denge sorunu, iktidar mücadelesi olarak ortaya çıkmaktadır (Akbulut 2005: 149). Weber’in görüşünü destekler şekilde, demokratik yönetimin gerekleriyle bürokratik yönetimin egemenlik eğilimi arasında bir çatışma bulunduğu ifade edilmekte, bu iki kurumun yapılarından kaynaklanan bazı farklılıklar içerdiği söylenmektedir (Tataroğlu 1997: 565).

Siyasi, sosyal ve ekonomik açıdan geçiş halindeki toplumların en belirgin özelliklerinden birisi olarak, kamu hizmetleri üzerinde tercihler yapma, öncelikler saptama ve diğer temel kararları alma yetkisine sahip kurumlarla, alınan bu kararları uygulama durumunda olan bürokratik mekanizmalar arasında yeterli bir dengenin kurulamamış olması gösterilmektedir. Bu tür toplumlardaki siyasal organların güçsüzlüğü, siyasal faaliyetlerin, büyük ölçüde, bürokratlar tarafından üstlenilmesi ile sonuçlanmaktadır (Riggs 1971: 64). Gelişmekte olan ülkelerde bürokrasi alanındaki gelişme ve değişmelerin, siyasal yapıdaki gelişme ve değişmelerden daha çabuk gerçekleştiği ve 
buna karşın bürokratik kurumların nispeten güçsüz olduğu bir ortamda, siyasal kurumların daha kolay gelişebildiği de öne sürülmektedir (Riggs 1971: 66-67).

1930 'lardan başlayarak ve 2. Dünya Savaşı'ndan sonra da yoğunlaşarak devletin toplumsal yaşama müdahalesinin artması sonucu düzenleme, gözetim ve denetim işlevlerine sahip merkezi bir bürokratik örgüt olarak devlet hızla büyümüş ve bu süreç 1980’lere kadar devam etmiştir (Akbulut 2005: 224227). Dolayısıyla, bu dönemde bürokrasinin her alanda etkin olduğunu ve demokratikleşme çabalarında da belirleyici bir rol üstlendiğini söylemek mümkündür. $\mathrm{Bu}$ görüşü destekler şekilde, bürokrasinin egemen olduğu toplumlarda yasaların parlamentolar tarafından kabul edilmesini sağlamak için temel girişimlerin bürokratlardan gelmekte olduğu görülmektedir. Bu durumun, bürokrasinin fiili gücünü kullanırken buna meşruiyet niteliği kazandırmaktaki becerisini ifade ettiği öne sürülmektedir (Riggs 1971: 87).

Bürokrasi, halkın siyasi temsilinin sağlanması şeklinde yapılandırılabilirse, kendisine atfedilen güç demokratik değerlerle uyumlu olabilir. Bunun yanı sıra, halkın bürokratik karar alma sürecine katılımının sağlandığı bir mekanizma kurulabilirse, bürokrasiler de demokratik sistemlerle uyumlu olabilirler. Bürokratik temsilin personel seviyesinde uygulanmasının demokratikleşme yolunda pek çok fayda sağlayacağını söylemek mümkündür (Tataroğlu 1997: 568). Kısacası, temsili bürokrasinin demokratikleşmeyi artırıcı yönde etkisi olduğu ileri sürülmektedir (Öztürk 2003: 43). Dolayısıyla bürokrasinin toplumu temsil edebildiği ölçüde demokratikleşmeye olumlu katkıda bulunacağını söyleyebiliriz. Kamu personeli kompozisyonuyla, yönetsel organizasyon tipiyle ve halkın yönetim birimlerinin faaliyetlerine katılması suretiyle bürokrasinin temsil fonksiyonu artırılabilir.

Demokrasi ve bürokrasi arasında, eşitlik ve eşit haklar çerçevesinde anlamlı ve olumlu bir ilişkinin varlığından söz edilebilir. Modern devlet yönetimlerinde bürokratik kuralların ve otoritenin gayrişahsi ilkelere dayanması, yasalar önünde herkesi eşit görme iddiasında olan demokrasi ile uyum göstermektedir. Öte yandan demokrasinin değerleri, bürokrasinin kapalı bir memurlar grubunun oluşturulmasının önlenmesi ve atanmışlardan oluşan memur kadrosunun otoritesinin azaltılması açısından anlamlıdır. Dolayısıyla çoğunluk tarafından oluşturulan bir düzen taraftarı olan demokrasi, 
elit bir yönetsel yapı oluşturulması düşüncesi ile karşıtlık gösterir (Aksan ve Çelik 2011: 6-7). Diğer bir ifadeyle, demokrasi ve bürokrasi arasında, doğalarından kaynaklanan bazı temel farklılıkların ve gerilimlerin olduğunu söylemek mümkündür (Bayram ve Çınar 2007: 16).

\section{Türkiye'de Demokratikleşme Süreci}

Batılılaşmayı, devletin çöküşüne engel olmak için ortaya atılan bir çözüm önerisi olarak kabul edebiliriz. Modernleşme anlayışını belirten "Batılılaşma" kavramı, Batı’nın kendine özgü kurumlarının ve yaşam biçiminin benimsenmesi anlamında kullanılmıştır. Türkiye'de modernleşmenin, devlet eliyle ya da tepeden inmeci olarak isimlendirilen müdahalelerle gerçekleştirilmesi söz konusudur. Cumhuriyet Türkiyesi'nde bu görevin bürokrasi kanadı tarafından yürütüldüğ̈ ve bu durumun bürokrasinin gücünün artmasına neden olduğu görülmektedir. Modernleşmeyi Batılılaşma anlamında ele alan "Türk Modernleşmesi” veya medeniyet projesi, sivil toplum üzerinde yükselmemiş, asker ve sivil bürokrasi üzerinde yükselmiştir. Bu doğrultuda bürokrasi, modernleştirici devlet görevlileri rolünü üstlenmiştir. Buradan hareketle, demokratikleşme konusunu da benzer bir çözümlemeyle ele almak mümkündür.

Türkiye tarihine bakıldığında; demokratikleşme sürecinin Osmanlı Devleti'nde Sened-i İttifak'la başlayan, Tanzimat Fermanı'yla hız kazanan ve Cumhuriyetin kurulmasından sonra da devam eden bir süreç olduğu; bu sürecin modernleşme ve Batılılaşma hareketlerine paralel geliştiği görülmektedir (Köktaş 2001: 121). Türk siyasal sisteminde çoğulcu, uzlaşmacı, gelenekçi ve liberal değerlerle merkeziyetçi, bürokratik ve elitçi değerler arasında bir çatışmanın mevcut olduğu ve bu çatışmaya dayalı dinamizmin siyasal gelişmenin hâkim çizgisini oluşturduğu kabul edilmektedir. Çoğulcu, gelenekçi ve liberal söylem II. Meşrutiyet, Birinci Meclis, Demokrat Parti yönetimi sırasında öne geçmiştir. Cumhuriyet döneminde "muasır medeniyet" içinde yer alabilmek için monarşinin yerine cumhuriyetin, din yerine milliyetin, şer’i kanunlar yerine seküler/laik kanunların yerleştirilmeye çalışılmasına karşın demokrasinin ihmal edilmesi neticesinde demokratikleşme çabalarının sınırlı kaldığını söyleyebiliriz. Bunun yanı sıra cumhuriyetçi, laik, milliyetçi, devrimci, devletçi ve halkçı bir ulus-devletin kurulması için gösterilen çabalar demokratik bir cumhuriyetin kurulmasını zorlaşıırmış, dahası böyle bir hedef ortaya konmamıştır (Dursun 1999: 22-23). 


\section{Bürokratik yönetim geleneği: Osmanlıdan Cumhuriyete devreden miras}

Osmanlıdan Cumhuriyet'e kalan en büyük miraslardan biri, bürokrasi egemenliğindeki köylü toplumu yapısıdır. Tanzimat'la birlikte Osmanlı devlet idaresi merkeziyetçi ve otoriter bir yapı arz etmeye başlamışı. Bu büyük bürokratik imparatorlukta devletin gerçekleştirdiği düzenlemeler siyasal-bürokratik elitin tercihlerine dayanmaktaydı. Tanzimat'la birlikte Osmanlı'dan Cumhuriyet'e kalan önemli miraslardan biri de, sivil-askeri bürokraside ortaya çıan ve zamanla kurumsallaşan siyasal iktidarı ele geçirme eğilimi ve bundan kaynaklanan elitler politikasının egemenliğidir. Cumhuriyetle beraber gerçekleştirilen devrimlerin de bürokrasiden geldiği görülmektedir. Cumhuriyet dönemi bürokrasisi, kendiliğinden oluşan bir bürokrasi değil, Osmanlı'dan miras kalan bir bürokrasi görünümündedir. Bu durum, bürokratik anlamda devamlılı̆̆ın ve aynı zamanda devlet elitlerinin devam edegelen egemenliğinin sürekliliğini ortaya koyması açısından önemlidir.

Osmanlı İmparatorluğu’nda bürokrasinin tutum ve davranışları geniş ölçüde siyasal normların etkisi altında kalmış ve bu durum bürokratik verimlilikten çok bürokratik ve siyasal etkinliğin ön plana alınmasına sebep olmuştur (Heper 1973b: 33). Dolayısıyla, bu dönemde bürokrasi siyasal kararları uygulayan değil, siyasal kararları alan ve aynı zamanda uygulayan konumunda olmuştur. Tanzimat döneminde yenileşme hareketlerini başlatan ve "Devlet nasıl kurtulur?" sorusuna cevap arayan sivil-asker bürokratlardır. Bu dönemde, özellikle sivil bürokrasi siyasetin yapıcısı rolünü üstlenmiştir. Bu durumun nedenini siyasetin yapılış biçiminde aramakta fayda vardır. Siyaset parlamento yoluyla değil, kural koyma yoluyla yapıldığı için bürokrasi siyaset yapımında söz sahibidir (Heper 1974: 58-59).

Tanzimat döneminde sivil bürokrasi ön plana çımış ve bürokratik elit yeni siyasi normların savunucusu ve yayıcısı olmuştur. Ancak Batılı kurumlara ve normlara geleneksel toplum karşı koymuş, yeni kurumların toplumda yerleşmesi için devamlı mücadele verilmek zorunda kalınmıştır. Sanayileşen Batıda bürokrasi "statü elit" görünümünü terk eder ve gelişen girişimci grupların siyasal egemenliği altına girerken, bu mücadele, bürokratik eliti siyasal çatışmanın tam ortasına itmiş ve Osmanlı bürokratik elitinin statü elite dönüşmesine yol açmıştır (Heper 1973b: 37).

Tanzimat döneminde sivil bürokratlar, devletin bürokratik kurumlarla tem- 
sil edilmesini istemektedirler. Bu dönemin önde gelen devlet adamları padişahın sistem içinde üstün konumunun korunmasını desteklerken, politika üretiminde inisiyatifin bürokratik elitlerde olması gerektiğini düşünmektedirler. Nitekim sivil bürokrasi Tanzimat döneminde siyasal etkinliği büyük ölçüde ele geçirmiştir. Bürokrasi için önemli olan alınmış kararları en verimli biçimde uygulamak değil, en iyi politikayı yapmaktır (Heper 1990: 148-149).

Tanzimat dönemi bürokratlarının temel özelliği devlet yönetiminde yalnızca kendilerini liyakatli gören, Batı tipi eğitim görmüş kapalı bir grup olmalarıdır. Kendilerini padişahın değil, devletin hizmetlisi olarak görmektedirler. Geçmişten süregelen bir gelenekle, kendileri tarafindan oluşturulan siyasetin kamu yararına olacağı ve genel iradeyi en iyi temsil edeceği düşüncesi hâkimdir. Üzerinde durdukları en önemli nokta sivil bürokrasinin siyasal bağımsızlığının sürdürülmesidir (Heper 1974: 69-70).

Sivil bürokratların oluşturduğu yapı, II. Abdülhamit döneminde tamamen tersine dönmüştür. Devletin kendi şahsında temsil edilmesi gerektiğini düşünen II. Abdülhamit, Bab-1 Âli'yi bir anlamda iş takipçisi daire pozisyonuna getirmiştir. Yine aynı şekilde Tanzimat'ın oluşturmak istediği liyakate dayalı memuriyetin yerine, kişisel sadakate dayalı bir bürokrasi oluşturulmaya çalışılmıştır (Hanioğlu 1989: 57-58). Tanzimat dönemi bürokratlarının etkili yönetim kademelerinden uzaklaştırılmasına rağmen, kazanılan bürokratik yönetim geleneği devam etmiş ve bürokratlar II. Abdülhamit'e karşı muhalefetin odak noktasını oluşturmuşlardır (Heper 1974: 59).

\section{Tek-parti döneminde bürokrasinin demokrasiyle imtihanı}

Osmanlı bürokrasisini devralan Cumhuriyet Türkiyesi, öncelikli olarak bu bürokratik yapılanmadan kurtulmanın yollarını aramıştır. Fakat patrimonyal izlerin silinmesi yeterli olmamış, ikili bir yapı ortaya çıkmıştır. Bununla birlikte Atatürk döneminde patrimonyal bürokrasi anlayışından rasyonel bürokrasiye geçiş yönünde önemli adımlar atılmıştır. Bunun için ilk olarak rejimle uyumlu yeni bir bürokratik kadronun tesisi sağlanarak bürokrasi, hukuki ve nakdi olarak güvence altına alınmıştır. Sivil bürokrasi adeta parti bürokrasisi ile özdeşleşmiştir (Şavkılı ve Aydın 2013: 75-78).

Tanzimat dönemine kadar uzanan bürokratik yönetim anlayışı, Cumhuriyetin ilanından Demokrat Parti'nin iktidara geldiği 1950 yılına kadar uzanan 
dönemde altın yıllarını yaşamıştır (Heper 1974: 89). Türkiye Cumhuriyeti Osmanlı İmparatorluğu’ndan güçlü bir devlet ve zayıf bir sivil toplum mirası devralmıştır. Bundan dolayı, Osmanlı döneminde olduğu gibi Cumhuriyet döneminde de bürokratik elit, toplumu bir arada tutmak için devleti zorunlu bir varlık olarak görmüştür (Heper 1985: 50). Geçiş dönemindeki toplumlarda siyasal organların güçsüzlügü̈, siyasal faaliyetlerin büyük ölçüde bürokratlar tarafından üstlenilmesi ile sonuçlanmaktadır. Ancak bu faaliyetlerin bürokrasi alanına kayması, genellikle siyasal istikrar, yönetsel etkinlik ve demokratik değerler açısından olumsuz sonuçlar doğurmaktadır (Riggs 1971: 64).

Tek-parti döneminde de devletle bütünleşen bürokrasi, Kemalist ilkeleri toplumda yerleştirme fonksiyonunu üstlenmiştir (Heper 1977: 72). Demokrasiye geçiş döneminde siyasal organların güçsüzlüğüne karşlık, bürokratik yapının sürekli gelişim içinde olması, devletin üstlendiği hizmetlerdeki artış sonucu kamu sektörünün sayı ve hacim olarak genişlemesi, buna karşın parlamenter kurumların fonksiyonlarını etkin olarak yerine getirememeleri bürokrasinin siyasal sistem üzerindeki etkisini ve belirleyici gücünü ortaya koymaktadır (Riggs 1971: 65).

Kemalizm'in temel ilkeleri, Cumhuriyet Halk Partisi (CHP)'nin 10 Mayıs 1931 tarihli Büyük Kongresi'nde kabul edilmiş, 1935 Programı’nda önemsiz bazı değişiklikler geçirdikten ve 1937 tarihinde de Teşkilâtı Esasiye Kanunu'nun 2. maddesine aktarıldıktan sonra değişmeksizin varlığını korumuştur (Köker 2005: 133). Kemalizm olarak tanımlanan CHP'nin altı ilkeli ideolojisindeki her ilkenin siyasal bir anlamı ve yönü olmakla birlikte; siyasal sistemle doğrudan ilgili ilkeler halkçılık, milliyetçilik ve cumhuriyetçiliktir (Öz 1992: 142).

Siyasi alanda Kemalizm'in hedefinin ne olduğu yeterince açı olarak ortaya konulmuş olmamakla birlikte; bu konuda Kemalizm'in esas olarak liberal demokrasiyi hedeflediği, ancak bu hedefe ulaşmak bakımından zorunlu olan reformların gerçekleştirilmesi için gereken bir geçici otoriter sistemin kurulmuş olduğunu kabul eden görüşler olduğu gibi (Köker 2005: 212-213), bunun aksini savunan görüşler de bulunmaktadır (Parla 1993). Dolayısıyla, günün koşullarına uygun olarak Kemalizm’in en azından demokrasiyi temel almadığını söylemek mümkündür. 
1930 'lardan sonra ekonomide uygulanan ve "devletçilik" ilkesi ile ifade edilen politikalar, bürokrasinin ekonomik yaşama da doğrudan ve etkili biçimde müdahalesine olanak sağlamıştır (Şaylan 1983: 300). Bürokratlar artan güç ve prestijleri itibariyle, politika uygulayıcı olmaktan çok, politika yapıcı olma isteğinde olmuşlardır (Heper 1985: 72). Cumhuriyet devrimlerinin ancak cumhuriyet ilkelerine bağlı bürokratik kadrolarla gerçekleştirilebileceğine inanıldığı için, Cumhuriyet' in ilk yıllarında yeni siyasal ve kültürel amaçları hayata geçirmek amacıyla, Cumhuriyetin temel ilkelerini benimsemiş yeni bir bürokratik yapıya ihtiyaç duyulmuştur ve bu bürokratik yapıyı oluşturmak için yoğun bir çaba sergilenmiştir (Göküş 2000: 24).

Cumhuriyet dönemi bürokrasisinin iki temel misyonu bulunduğu kabul edilmektedir. Buna göre, reformları geliştirerek devam ettirme ve ekonomik kalkınmada bürokrasinin öncüllüğünü sağlama görevi bürokrasiye verilmiştir (Eryılmaz 2010: 137). Bunun yanında devrimleri halka kabullendirme misyonu da bürokrasiye verilmiştir (Göküş 2000: 24). Cumhuriyet dönemi bürokratı, kendilerinin varlık nedenini devlete bağlamıştır. Devlet onların nihai sadakatlerini ve hizmetlerini sundukları kurum olmuştur. Bu nedenle devletin yaşatılması ve güçlendirilmesi, bürokrasinin en önemli amacı olmuştur. Devlet konusunda Osmanlidan kalan bu mirasın önemli bir sonucu ise reform girişimlerinin elitist ve merkez eksenli olmasıdır (Göküş 2000: 25). Kuşkusuz bu durumun demokratikleşme açısından olumlu bir görüntü oluşturduğunu söylemek mümkün değildir.

Cumhuriyet'in ilanından, çok-partili hayata geçişe kadar olan dönemde siyasal elitle bürokratik elit kaynaşmıştır. CHP yönetimi altında ülkenin siyasal elitleri ile özdeşleşmiş olan bürokrasi, devrimlerin topluma aşılanmasında da en etkin rolü oynamışır (Göküş 2000: 25). Cumhuriyet döneminde bürokratik elitin milliyetçilik, halkçllık ve devletçilik ilkelerinde yeni bir "seküler-emredici-kapsamlı" norm sistemi bulduğu ve bu ilkeleri kendi "ideal" kamu yararı kavramına temel taşları yaptığı kabul edilmektedir (Heper 1973b: 37).

Çok-partili hayata geçiş sürecinde, bürokratik yönetim geleneği yeni siyasal kadrolarla çatışmıştır (Heper 1973a: 115). Bürokratik elit, gerek halkı gerekse de yeni siyasal kadroları demokrasi için uygun bulmadığı gibi, siyasi makamları dolduran "çevre" nin temsil edilmesine de hoşgörüyle bakmamıştır (Heper 1985: 77). Her ne kadar 1924 Anayasası çoğulcu rejime kapalı 
olmadığı ve demokratikleşmenin önünde bir engel oluşturmadığı için 1924 yılında Terakkiperver Cumhuriyet Firkası, 1930 yılında ise Serbest Cumhuriyet Firkası kurularak demokrasi denemeleri yapılsa da (Ertan 2012: 4-5); devletin ve yeni kurulan cumhuriyetin siyasi, ekonomik ve toplumsal dengeleri henüz tam oturmadığ 1 için demokratikleşme ve çok-partili hayata geçişte söz konusu iki teşebbüs başarılı olamamıştır (Taşkıran 1994: 264-265). Bu dönemde bürokrasinin Türkiye'de demokratikleşmenin sağlanmasından ziyade Kemalist devrimin korunması peşinde olduğu görülmektedir (Heper 1985: 87). Nitekim yeni siyasal kadroya rağmen, bürokratik elit siyasal etkinliğini sürdürmeye çalışmıştır.

1940'larda yaşanan gelişmeler sonucunda bürokratik elitin Kemalist devrimin önderliğini üstlendiği görülmektedir. 1950'de CHP seçimi kaybedince, bürokrasi demokrasi ile birlikte devrimlerin de korunması misyonunun kendisine düştüğüne inanmıştır (Heper 1974: 120). Bu düşüncenin günümüze kadar etkisini sürdüren bürokratik vesayetin temellerini oluşturduğunu söylemek mümkündür. Nitekim tek-parti dönemi demokrasi anlayışının halk egemenliğine dayanan, çoğulcu anlayışa sahip ve demokratik sistemin temel kurum ve kurallarını içeren bir yapıdan ziyade devlet otoritesinin sağlanması ve cumhuriyetin ilkelerinin benimsetilmesine odaklandığı görülmektedir.

"Demokratik devlet, resmi ideolojisi olmayan ve vatandaşlarına resmi ideoloji baskısı uygulamayan devlettir” tezinden hareketle; kuruluşundan 1950’li yıllara kadar Türkiye Cumhuriyeti'nde açık ve kapalı uygulamalar içinde resmi ideolojinin var olduğu ve buna dayanarak, söz konusu dönemin ve uygulamaların demokratik olmadığı ileri sürülmektedir (Eriş 1997: 665).

\section{Bürokratik yönetim geleneğinde kırılma noktası: çok-partili hayata geçiş}

Türkiye'nin tek-parti rejiminden çok-partili sisteme geçişinde siyasi, sosyal ve ekonomik iç gelişmelerin yanı sıra; Birleşmiş Milletler Anayasası'nın imzalanması, II. Dünya Savaşı́nın demokrasi cephesinin kazanması sonucu dünyaya hâkim duruma geçen demokratik ideolojilere Türkiye'nin kendi siyasi rejimini uydurma zarureti gibi dış etkenlerin de belirleyici olduğunu söyleyebiliriz (Karpat 1996: 125). Diğer bir ifadeyle, iç dinamiklerde yaşanan önemli değişikliklerle birlikte, esas olarak dış faktörlerin etkisiyle çok-partili siyasal hayata geçilmiştir (Köktaş 2001: 126-127). Yönetim kadrolarında keyfi uygulamalara gidilmesi ve işe alımların suiistimale açı 
olması, bürokratik uygulamaların halkın yönetime yabancılaşmasına sebep olması, bürokratik elitlerle zengin toprak sahipleri arasındaki işbirliğinin azalması gibi faktörlerin çok-partili hayata geçişte etkili olduğu öne sürülmektedir (Akıncı ve Usta 2015: 47). Buradan yola çıkarak, bürokrasinin bu süreçte etkin bir aktör olarak öne çıktı̆̆ını söylemek mümkün görünmemektedir.

Türkiye'nin 1946 ile 1950 yılları arasındaki demokratikleşme süreci, demokrasiye geçişin reform şeklini tayin etmektedir. Geçiş süreci dönemin otoriter rejiminde siyasal iktidarı elinde tutanlar tarafından başlatılmış ve dikkatlice denetlenmiştir (Özbudun 2003: 23). 1946 ile 1950 arasında Türkiye'de demokrasiye geçiş sürecinde Demokrat Parti (DP) muhalefetinin Hükümeti müzakereli bir anlaşmaya zorlayacak gücünün bulunmadığı görülmüş; Hükümet ordu ve bütün devlet örgütünün desteğiyle demokrasiye geçişin her evresini kontrol edebilmiştir (Özbudun 2003: 24).

II. Dünya Savaşı sonrasında tek-parti idaresini sona erdiren ve ülkeyi liberal ve parlamenter demokrasi modeline oturtan hızlı ve ani değişikliğin gelmesi, 1950'de iktidarın değişmesine yol açmıştır (Lewis 1998: 303). Ancak tek-partiye göre tasarlanmış siyasal sistem ve alışkanlıkların çoğulcu yapının düzgün işlemesine engel olduğu görülmüştür. Bu dönemde bürokratlara dayalı merkez ile demokrat kenar arasındaki çekişmenin iyice su yüzüne çıktığ ifade edilmektedir. Tek-parti zihniyet ve alışkanlıkları ile yetişen elitist ve bürokratik sınıf yeni döneme uyum sağlayamamış ve direnç geliştirmiştir (Yilmaz 1997: 533).

Bu tespitin aksine, 1945 sonrası siyasi gelişmelerin 1924 Anayasası'nda o zamana kadar kuramsal düzeyde kalan pek çok konuya gerçeklik kazandırdığ da ileri sürülmektedir. Buna göre anayasal hükümlere dokunulmazken, dernekler kanunu, ceza ve seçim kanunlarında yapılan değişikliklerle birlikte idari uygulamalardaki koşut değişikliklerin 1950 'de hükümet olacak etkili bir anayasal muhalefetin oluşmasına ve işlerlik kazanmasına olanak tanıdığ ifade edilmektedir (Lewis 2007: 14). Nitekim 1950'de CHP'nin yenilgisinin ve iktidarı bırakmasının, bu partinin Cumhuriyetin kuruluşundaki başarılarından birisi olduğu görüşü de bu düşünceyi destekleyen diğer bir husustur (Lewis 2007: 9).

Bürokratlar, büyük toprak sahipleri, tüccar, sanayici ve yerel eşraftan oluşan 
ve CHP'de somutlaşan zımni koalisyon, 1945 yılında II. Dünya Savaşı'nın bitmesiyle birlikte sosyal, ekonomik ve siyasi nedenlerden dolayı bozulmuş, böylece geniş tabanlı toplumsal muhalefetin isteklerini yanıtlayan siyasi parti olarak DP gelişme ortamı bulmuştur (Çavdar 2004: 16-17).

Mustafa Kemal döneminde belli bir istikrara kavuşan toplumsal düzenin ve II. Dünya Savaşı'nda izlenen politika sonucu geçirdiği gelişimin bir ürünü olarak tanımlanan DP (Timur 2003: 23); savaş yıllarında izlenen politikaların halkın bürokrasiden soğumasına neden olması ve savaş sonunda demokratik rejimlerin saygınlık kazanması neticesinde tek-parti sistemine alternatif olabilecek bir yapı arayışlarını, kısacası demokratikleşme sürecini başlatmıştır (Timur 2003: 26-29). Diğer açıdan bakıldığında, savaş sonunda CHP varlıklı sınıfların bir kesimiyle baskı aracı niteliğine dönüşmüş bürokrasinin temsilcisi durumunda kalmıştır (Timur 2003: 30).

Tek-parti döneminin seçim yasası uyarınca yapılan 1946 seçiminin en sakıncalı yanının tasnif işlemlerinin gizli ve çoğunlukla memurlardan oluşan sandık kurulu ve üst komisyonlarca yapılması olduğu kabul edilmektedir (Çavdar 2004: 13-14). DP'lilerin de bu seçimde memurların tutum ve uygulamalarından şikâyetçi oldukları bilinmektedir (Karpat 1996: 142). Nitekim bu seçimlerin sonucunda, seçim hizmetlerini yürüten idarenin iktidarı kollaması neticesinde CHP 403 milletvekili alarak seçimleri kazanmıştır (Karatepe 2001: 100).

Seçimlerin yargı yönetimi ve denetiminde gerçekleştirilmesi için 1950 seçimlerinden hemen önce yasal düzenlemeye gidilmiştir. ${ }^{1}$ Buna göre, Milletvekilleri Seçim Kanunu ile illerde ve ilçelerde Seçim Kurulları oluşturulmuş, ayrıca Ankara’da görev yapmak üzere Yüksek Seçim Kurulu (YSK) kurulmuştur. Bu Kanun ile seçim güvenliği, yönetimi ve denetimi yeni kurallara bağlanmış, seçim sürecinde yargı denetimi esası getiren Kanun, seçim işlerinin seçim kurullarınca yürütüleceği ve seçim kurullarının bütün işlerinin görülmesinde yargıç gözetim ve denetimine tâbi olacağını da hükme bağlamışır. Dolayısıyla, bürokrasinin seçimler üzerinde var olan etkisi YSK'nın kurulmasıyla birlikte büyük ölçüde azalmış ve demokratikleşme yolunda hiç de azımsanmayacak bir adım atılmıştır.

1950 yılında seçim idaresi sorumluluğunun valilerden ve dolayısıyla bürokrasiden alınıp büyük ölçüde bağımsız olan yargıçlara aktarılması ile serbest 
seçimlerin gerçek anlamda mümkün kılındığını söylemek mümkündür. Bu seçimlerde seçmenin \%88'i sandık başına gitmiş ve sonuçta 408 DP'li, 69 CHP'li, 1 Millet Partili ve 9 bağımsızdan oluşan meclis kurulmuştur (Lewis 1998: 311). Hiç kuşkusuz bu sonuçta seçimlerin bürokrasiden bağımsız olarak YSK'nın yönetimi ve denetimde yapılmasının büyük payı vardır.

Bürokrasinin siyaset, yönetim ve dolayısıyla kamu yararı felsefesi ile DP'nin kamu yararı görüşü arasında büyük farklılık bulunması sebebiyle, çok-partili hayata geçildiğinde bürokrasinin değişen siyaset ve çevre faktörlerine karşı uyumu ve kendini buna göre değiştirmesi kolay olmamıştır. Ayrıcalıklı konumunu terk etmek istemeyen bürokrasi ile onu kendi siyaset anlayışına yakınlaştırmak isteyen siyasi iktidar arasında bir mücadele yaşanmışıı (Eryılmaz 2010: 145-146).

Çok-partili hayata geçildikten sonra prensip olarak bürokrasinin iktidar karşısında tarafsız, siyasal işlevlerden arındırılmış ve karar ve kuralları uygulamakla görevli nispeten özerk bir aygıta dönüşmüş olması gerekirken o güne kadar kazandığı geleneksel siyasal norm ve alışkanlıklar ve yerleşmiş kuralların da etkisiyle siyasal oluşumlarda rol oynamaya devam ettiği, "milli menfaat" gibi kavramları tanımlamaya çalışı̆ı̆ı, yer yer siyasal grup ve aktör olarak davrandığı, tek-parti dönemindeki "toplumu inşa" misyonunu sürdürmek istediği gözlenmektedir (Dursun 2006: 328).

DP ile iktidara gelen yeni siyasal elitin icraatlarına geleneksel kenar kesimler destek vermiş, buna karşın bürokrasi ve aydın kesimin tepkisi gecikmemiştir. Yeni elitin ve "kenar" kesimlerin topluma yön vermede söz sahibi olmaları aydınlar, bürokrasi ve CHP tarafından kabul edilememiştir. Bu durum karşısında DP iktidarı, bürokrasinin siyasal alandaki etkisini ve işlevlerini sınırlandırmak ve bu alanda seçilmiş kişileri aktif hale getirmek için çeşitli düzenlemeler yapmak zorunda kalmıştır (Dursun 2001: 22).

DP dönemine kadar temel kararların alınmasında etkili ve tek söz sahibi olan "devlet"le bütünleşmiş "bürokratik iktidar", 1950 sonrasında gücünü ve etkisini kademeli olarak kaybetmiş, siyasal hayatta toplumun istekleri daha ağılık kazanmaya başlamıştır. Statükoyu zorlayıcı bir etki olarak toplumsal baskı bürokrasi aleyhine genişlemeye başlamış; bu durum bürokratik iktidarın tepki ve karşı koyması ile karşılanmışıı (Eroğul 1970). Bu noktada DP seçimleri kazanmak ve sonuçta bürokrasinin siyasal sistem içindeki ye- 
rini değiştirmeye yönelik yaptığı girişimlerin başarısızlı̆ga uğramaması için en azından bürokrasinin tarafsızlığının sağlanmasını gerektiğini düşünmüştür (Ahmad 1995: 155). DP iktidarı, gerek muhalefet döneminde gerekse iktidarı döneminde bürokrasi konusundaki söylemlerinin büyük kısmına uyarak bürokrasiye yönelik politikalarında bir ölçüde başarılı olmuştur. Fakat 1950 'lilerin sonunda sivil bürokrasi, gelişmiş ülkelerde olduğu gibi yalnızca siyasal kararları uygulayan bir kurum durumuna indirgenememiştir. Bu dönemde ilgili olarak başta $6422^{2}$ ve $6435^{3}$ sayılı kanunlar olmak üzere bir takım düzenlemelerle profesyonel, liyakate dayalı normlara göre çalışan bürokrasinin gelişimi de engellenmiştir (Göküş 2003: 60).

Bürokrasinin tarafsızlığının sağlanmasının demokratikleşme için önemli bir adım olduğu, bu noktada gerek siyasilerin gerekse bürokratların hesap verebilir olmasının demokratikleşme sürecine olumlu katkı sağlayacağı düşünülmektedir (Behn 2001: 5-6). Siyasi aktörlerin yanında bürokratik aktörlerin de politika yapım sürecinde rol aldıkları göz önünde bulundurulduğunda, kamuoyuna hesap vermeyen bürokratlar tarafından politika yapılmasının olumsuzluklarına dikkat çekilmekte ve hesap verebilirlik ilkesinin demokratikleşme sürecinde ortaya çıkan aksaklıkları gidermede önemli rol oynağ kabul edilmektedir (Gormley ve Balla 2012: 12).

Kamu örgütlerinde yetki ve otoriteyi elinde tutanların kendilerinden beklendiği şekilde davranıp davranmadıklarının belirlenebilmesi için bir tür "hesap verebilirlik" yönteminin bulunması gerekmektedir. Bu noktada hesap verebilirlik anlayışının kamu örgütlerinde hayata geçirilmesi, bürokrasi ile demokrasinin uzlaştırılmasına katkıda bulunacaktır. Diğer bir ifadeyle, hesap verebilir bir kamu yönetimi sisteminin geliştirilmesi bürokrasi-demokrasi çatışmasını da azaltabilecek potansiyellere sahiptir (Balcı 2005: 331). Hesap verebilirlik ilkesinin temel özelliklerinin kişinin dışındaki başka bir kişi ya da otoriteye açıklamada bulunması, sosyal etkileşim ve karşılıklılık içermesi, hesap sorabilme hakkının kabul edilmesi olduğu düşünüldüğünde (Eryılmaz ve Biricikoğlu 2011: 22); genel olarak hesap verebilirlik ilkesi ile bürokrasinin tarafsızlı̆̆ının sağlandığını ve böylelikle bürokrasi-demokrasi arasındaki gerilimin azaldığını söylemek mümkündür.

DP döneminde bürokrasinin gücünü azaltmak için "Bakanlık emrine alma", "Res'en emekliye sevk etme", "Hükümet işlerine karşı Danıştay yolunu kapama" gibi önlemler hayata geçirilmiş ve böylelikle bürokrasi ikti- 
dara bağımlı hale getirmiştir. Bu doğrultuda TBMM'de bürokrat kökenli milletvekili sayısında da bu dönemde hızlı bir düşüş olmuştur (Şaylan 1983: 305). Bu dönemde bürokrasi ülke yönetimindeki ağırlığını iyice kaybetmiştir. Bürokratlar parlamentodaki hâkim konumlarını ve siyasal seçkinlerle olan güçlü bağlarını kaybettikleri gibi, genel olarak, nüfuzlarını, statülerini, itibarlarını, güvenliklerini ve gelirlerini de büyük ölçüde kaybetmişlerdir (Özbudun 1995: 17).

DP açısından bürokrasinin siyasal hayatta "yönetici zümre" olarak oynadığı rol ve iktisadi hayatı düzenlemede yüklendiği görev eleştiri konusu olmuştur (Timur 2003: 135). Bu dönemde bürokrasinin siyasal rolü ve gücünün azaltılması, "iktidar emrine memur" anlayışı yerine "kanun emrinde ve milletin hizmetinde memur" anlayışını yerleştirmek için (Tutum 1972: 84); bakanlık emrine alma, resen emekliye sevk etme, hükümetin işlerine karşı yargı yolunu kapatma şeklinde gerçekleştirilen bazı yasal düzenlemeler yapılmış ve böylelikle CHP ile bütünleşmiş üst düzey bürokratların otonomisi kırılmak istenmiştir (Şaylan 1983: 305).

Tek-parti dönemi boyunca siyasal rolü ve gücü doğrultusunda "sosyal değişim ajanı” görevini üstlenen bürokrasi, çok-partili hayata geçişle birlikte hem yasama organı tarafından denetlenen hem de yürütme organının bir kolu gibi çalışan kurumsal yapı olarak görülmek istenmiştir. Bu nedenle DP iktidarı döneminde bürokrasinin rolünün azaldığını söylemek mümkündür (Özbudun 1995). Bürokrasinin siyasal gücünü azaltmaya yönelik çabalar bir ölçüde başarılı olmuştur. Ancak bununla birlikte, DP iktidarında bürokrasi yalnızca siyasal kararları uygulayan bir konuma indirgenememiş, "bürokratik yönetim geleneğì" 1950'lerin sonunda da siyasal hayatta rolünü ve gücünü korumuştur (Heper 1974: 140-141).

1950-1960 dönemi demokratikleşme açısından ele geçirilmiş büyük bir firsat olmakla birlikte, bu firsatın yeterince iyi değerlendirilemediği de ileri sürülmektedir. 1908'den bu yana ilk kez demokratik teamüllere uygun olarak bir iktidarın işbaşına gelmesine karşın, bu iktidarın muhalefet yıllarında seçim meydanlarında vaat ettiği özgür ve düzenli seçimler, siyasi çoğulculuk, çoğunluk yönetimi, sivil-siyasi-iktisadi özgürlükler gibi demokratik kuralları ve kurumları yaşama geçiremediği görülmektedir. 22 Mayıs 1950 - 09 Mart 1951 tarihleri arasında görev yapan ilk DP hükümeti (19. Hükümet) döneminde, programda yer alan antidemokratik yasalar ayıklanmamıs, ak- 
sine kısa sürede bu yasalara sığınılarak eski uygulamalara devam edildiği görülmüştür (Çavdar 2004: 80).

Son olarak, DP iktidarını sonlandıran ve demokratikleşme sürecinin kesintiye uğramasına neden olan "27 Mayıs Darbesi”ni, bürokrasinin kısmen de olsa etkisini yitirdiği siyasal rolü ve gücünü sürdürme gayreti çerçevesinde değerlendirebiliriz. Bu hususta DP iktidarınca uygulanan politikalardan rahatsız olan bürokrasi, yeni siyasal elitin öne çımasına ve giderek siyasal işlevleri elinden almasına tepki göstermekte gecikmemiştir (Dursun 2001: 22-23). Başta ekonomik gelişmeler sivil ve askeri bürokrasi içinde tedirginlik doğurmuş, ordu içinde ortaya çıkan yığılmalar ve maaşların düşüklüğü huzursuzluğu giderek artırmış (Koçak 2001: 152); iktidarın izlediği politikalardan rahatsızlık duyan bürokrasi darbenin şartlarının oluştuğu fikrini kabul etmiştir. Basit bir gerekçe gibi görünse de, Silahlı Kuvvetler personelinin yaşantı ve hayat standardı ile ilgili sorunların tedirginlik doğurduğu ifade edilmektedir (Aydemir 2000: 266-270).

Dönemin Kara Kuvvetleri Komutanı Orgeneral Cemal Gürsel'in 3 Mayıs 1960'da Milli Savunma Bakanı Ethem Menderes'e yazdığı mektup, ordunun, dolayısıyla bürokrasinin DP uygulamalarından kaynaklanan tedirginliğini ve rahatsızlığını yansıtması bakımından önemlidir (Tunçkanat 1996: 259-261). Nitekim bürokrasi ve elit kesiminden oluşan "Devletçi İttifak"ın siyasal rolünü sürdürmek ve statükoyu korumak amaciyla yönetime el koyması anlayışı, 27 Mayıs 1960 Darbesi ile Türk siyasal hayatına girmiştir.

DP iktidarı döneminin bürokrasinin rolünün azaltılması bağlamında değerlendirilebileceğini ifade eden Özbudun (1995: 18), 1960 Darbesi'nin asker ve sivil bürokrasinin Türk toplumundaki iktidar, statü ve itibarlarının gerilemesine karşı ortaya çıan tepkisi olarak görülebileceğinden söz etmektedir. Benzer bir görüş ileri süren Göle de (1998: 80), 1960 Darbesi’ni yapanların ekonomik ve sosyal alanlarda yürütülen liberal politikalara tepki duyan, devletçi ve laik geleneğe sahip bürokrat ve aydınlara dayandığını belirtmektedir.

Kısaca ifade etmek gerekirse, DP iktidarında siyasal rolü ve gücü kısmen de olsa azalan bürokrasi, eski gücüne ve etkinliğine kavuşmak için 27 Mayıs 1960 Darbesi'nin ortaya çıkmasında önemli rol oynamış ve bunun sonucunda Türk siyasal sistemi içinde var olan "bürokratik vesayet" rejimini sürdürmeye devam etmiştir. 


\section{Sonuç}

Bir ülkede demokrasinin varlığının temel göstergelerinden biri de, kamusal sorunlar hakkındaki temel belirleyici kararları seçilmiş görevlilerin alması ve göreve geliş yöntemleri bakımından halkı temsil etmeyen atanmış kamu görevlilerinin seçilmiş iktidarların denetimi altında olmasıdır. Buradan hareketle, bazı demokrasi teorisyenlerinin "seçilmişlerin atanmışlara üstünlügü̈”nü demokrasinin ilkeleri arasında saydığı ifade edilmekte; ancak Türkiye'de durumun pek de böyle olmadığına vurgu yapılmaktadır (Erdoğan 1997: 56).

1950 seçimlerinde cumhuriyetin ilanından itibaren ülkeyi tek başına yöneten CHP iktidarı sona ermiş ve DP'nin 10 yıllık iktidar dönemi başlamıştır. 14 Mayıs 1950'de yapılan seçim, öncesinde çıkarılan 5545 sayılı Milletvekilleri Seçim Kanununa göre tek dereceli, eşit, gizli oy ve açık tasnif usulüne göre adli denetim altında yapılan ilk seçim özelliği taşımışıı. 1950, 1954 ve 1957 seçimlerinde "tek dereceli liste usulü çoğunluk sistemi" uygulanmıştır. $\mathrm{Bu}$ sisteme göre her seçim bölgesinde kullanılan oyların çoğunluğunu alan parti o seçim bölgesinin tüm milletvekilliklerini de kazanmıştır. Seçmenlerin \% 89,3'ünün sandık başına gittiği 1950 seçimi sonucunda DP \% 53,35 oy ile 408 milletvekili, CHP \% 38,38 ile sadece 29 milletvekili kazanmıştır (Duman ve İpekşen 2013: 120). DP 1954 seçiminde gücünü korumaya devam etmiş, oyların \% 57,50'sini alarak 502 milletvekili, CHP \% 35,29'luk oranla 31 milletvekili, Cumhuriyetçi Millet Partisi 5 milletvekili çıkarmıştır. Üç bağımsızla birlikte toplam 537 milletvekili seçildiği 1954 seçiminde katılım oranı 0,7 puan düşerek yüzde 88,6 olmuştur. 1957 seçiminde seçime katılım oranı 12 puan düşmüş ve \% 76,6'ya gerilemiştir. DP ilk kez \% 50 'nin altına düşerek \% 47 oy almıştır. CHP ise oy oranını \% 41'e çıkarmıştır. DP 78 sandalyesini kaybederek 424 milletvekiliyle temsil edilmiş, CHP ise 147 yeni sandalye kazanmış ve milletvekili sayısını 178'e yükseltmiştir (Duman ve İpekşen 2013: 121-122). Dolayısıyla bu tablo, DP iktidarı döneminde bürokrasinin tarafsızlığının sağlanmasında, atanmışların temsilinden kaynaklanan problemlerin çözümünde ve demokratikleşme sürecinde önemli adımlar atılmasına rağmen çok-partili hayata geçişle birlikte seçim sisteminden kaynaklanan temsil sorunun devam ettiğini göstermektedir.

Türkiye'nin demokratikleşememesinin ve halkın tercihine göre bir yönetimin oluşmamasının temelinde "bürokratik yönetim geleneği" tarihsel mi- 
rasının payı olduğu görüşünü öne sürmek mümkündür (Bilgin 1997: 26). Devletçi elitlerin her dönem rakip güç olarak karşısına çıan grupları bir diğeriyle mücadele içinde göstererek ve bu şekilde pozisyonlarını da güçlendirerek devlet mekanizmasını ellerinde tuttukları, devlet içerisinde toplumun değişik katmanlarının temsilini engelledikleri ve bu şekilde demokratikleşme açısından olumsuz nitelik taşıdıkları kabul edilmektedir (Durgun 1997: 46).

Türkiye'de cumhuriyete geçişle birlikte modernleşme-Batılılaşma anlamında oluşan yeni değerlerin ve kurumların yerleşebilmesi adına çağdaşlaşmaya dönük bir kadroya duyulan ihtiyaç, Türkiye'nin kurumlarını yaratacak ve yaşatacak olan kadro, bürokratik bir orta sınıf ile giderilmiştir. Bu sınıfın, yeni devletin temel felsefesini yaşayacak ve yaşatacak bir fonksiyona sahip kılındığını ve "devrim misyonerliği” görevini üstlendiğini söylemek mümkündür. Çünkü yeni Cumhuriyet' in medeniyet projesi sadece devletin yapısını değiştirmekle kalmamış, insanların yaşam biçimlerine ve gündelik alışkanlıklarına kadar her alana müdahil olma ve nüfuz etme isteğini ortaya koymuştur. Bu yeni toplumsal yapı oluşturulurken en önemli görev, Osmanlı döneminden miras alınan bir bürokratik yönetim geleneği olan bürokrasiye düşmüştür ve bu dönemde bürokrasi kilit bir rol üstlenmiştir.

Dolayısıyla bürokrasiye, "modernleştirici misyoner kurum" veya "hizmet gören modernleştiriciler" denilebilmektedir. Osmanlıdan miras olarak alınan bürokratik yönetim geleneği çerçevesinde, devrim misyonerliği görevini üstlenen bürokrasi daha çok siyasal bir görev üstlenmiştir. Bürokrasinin bu niteliğinde, çok-partili hayata geçişle beraber bir kırılma olmuş ancak izlerini günümüze dek getirmiştir.

Modernleşmekte olan bir ülkenin öncü kadroya olan gereksinimi, bürokrasinin daha çok siyasal rol üstlenmesi ve modernleştirici misyonerler niteliğini kazanması sonucunu doğurmuştur. Bu anlamda Türk kamu bürokrasisi, "toplum kurma" siyasal amacını ilke edinmiş, modernleştiriciler rolüyle siyasal elitlere karşı mesafeli ve kuşkucu tavırlar geliştirmiştir. Bunun bir diğer yansıması da bürokrasinin kendini partiler ve tabakalar üstü gören ideolojik haklılaştırımı olmuştur.

Bürokrasi, "toplum kurma" siyasal amacı veya modernleştirici aracı rolü nedeniyle topluma kuşkulu bir gözle bakmış, bu durum merkez-çevre çatış- 
masını doğurmuştur. Merkez, potansiyel bir muhalefet alanı olarak gördüğü çevre'yi sürekli sıkı bir denetim altında tutmaya çalışmıştır. Toplum kurma idealiyle hareket eden ve bunun Batılılaşmadan geçtiğine inanan bürokrasi, Batı kültürünü halka kabul ettirme uğraşı içinde olmuştur. Bu durum bürokrasinin halktan kopuk bir yapı içine girmesine ve çevrenin merkeze karşı bir husumetinin oluşmasına neden olmuştur. Bu anlamda halkın kendisine tepeden bakan bürokrasiyi daima yabancı olarak görmesi söz konusudur.

Bürokrasi, modernleşmeyi sağlamak için halka kamu hizmeti götürmek yerine halkı siyasal ideolojiye bağlamaya çalışıştır ve liyakat yerine siyasal bağlılık ilkesi öncelik taşımıştır. Tek-Parti döneminde bürokrasi, açıkça siyasetle uğraşır durumdadır. Bürokrasinin siyasal kararlara katılma arzusu, bazı kırılmalara uğramakla beraber günümüze kadar etkisini sürdürmüştür. Bürokrasideki bu yapılanma, bürokrasi açısından işlevsel farklılıkları ortaya çıkarmış, kamu görevi yerine getirmekle görevli bürokrasi, bundan ziyade modernleştirici araç rolüne bürünerek halka Cumhuriyet ideolojisini benimsetme görevini üstlenmiştir. Bürokrasi bakımından devrim ilkelerinin korunması, bürokrasinin verimli bir kurum olarak çalışmasından çok daha önemlidir.

Görüldügü üzere bürokrasinin demokratikleşme sürecine katkısı ile demokratikleşme arasında doğrudan bir ilişki bulunmaktadır. Demokrasinin gerekleri sağlanabildiği ve demokratikleşme mümkün kılınabildiği ölçüde, bürokrasi de bu süreçte olumlu bir rol oynamaktadır. Başka bir deyişle, bürokrasinin antidemokratik bir yapıya büründüğü ve otoriter uygulamaları hayata geçirdiği bir ortamda, genel olarak demokrasinin varlığından söz edilemeyeceği ortadadır.

Bürokrasi kavramı özü itibariyle demokrasi açısında çok da uygun olmayan bir nitelik taşısa da, az gelişmiş ve gelişmekte olan ülkeler açısından bürokrasinin, dolayısıyla bürokratikleşmenin demokrasinin hayata geçirilmesi ve demokratikleşmenin sağlanması için olumlu sonuçlar doğurabileceği de gözden kaçırılmamalıdır. Bununla birlikte, demokrasinin gerekleri ile bürokrasinin gereklerinin farklı olduğu ve bürokrasinin demokrasi açısından temel bazı olumsuzluklar taşıdığı da kabul edilmektedir.

Sonuç olarak Türkiye Cumhuriyeti' nin kuruluşu ve çok-partili hayata geçiş dönemi göz önüne alındığında; "demokrasi" ile "bürokratik vesayetçilik" 
arasında sürüp giden çatışmaların süreklilik arz ettiği, 1945'e kadar bürokratik vesayetçiliğin baskın olduğu ve günün şartlarına da uygun olarak demokrasinin ikinci planda yer aldığı, ancak daha çok dış faktörlerin belirleyici olduğu II. Dünya Savaşı sonrasında çok-partili hayata geçişle birlikte, 1960 Darbesine dek bürokratik vesayetin yerini yavaş yavaş demokrasiye bıraktığı görülmektedir. Kuşkusuz bu dönemle birlikte bürokratik vesayetçiliğin Türk siyasi hayatında etkisini ve önemini yitirdiğini söylemek iddialı olmanın ötesinde, doğruluğu da tartışılır bir tespittir. Bu durum, Shils'in (1960) çalışmasında kavramlaştırdığı "vesayet demokrasisi” nin hâkim olduğu bir yönetim sistemini ortaya çıkarmışır. Türkiye'de demokrasinin gelişim süreci incelendiğinde bürokrasinin birçok aktüel soruna sahip olduğu görülmektedir. Bürokrasinin demokratik değerlere göre daha öncelediği "üstün çıkar"ları ve kamuoyuna karşı doğrudan sorumluluk taşımaması, siyasi iktidara yönelik müdahaleleri ortaya çıkarmaktadır. 1990 sonrası dönemde siyasetin bürokrasiyi kontrol altına alması, bürokratlarla ilgili yasal düzenlemeler, yönetimde açılklk ve hesap verebilirlik, kamu yönetimi reformları gibi kurumsal ve yasal düzenlemeler bürokrasinin siyaset karşısında zayıflamasına yol açmıştır. Ancak tüm bu gelişmelere rağmen günümüzde de bürokratik vesayetin etkisini sürdürdüğünü söylemek mümkündür.

\section{Açıklamalar}

$1 \quad$ 16.02.1950 tarih ve 5545 sayılı Milletvekilleri Seçim Kanunu.

$2 \quad$ 25.06.1954 tarih ve 6422 sayılı Türkiye Cumhuriyeti Emekli Sandığı Kanununun Bazı Maddelerinin Değiştirilmesine Dair Kanun.

3 08.07.1954 tarih ve 6435 sayılı Bağlı Bulundukları Teşkilat Emrine Alınmak Suretiyle Vazifeden Uzaklaştırılacaklar Hakkında Kanun.

\section{Kaynaklar}

Ahmad, Feroz (1995). Modern Türkiyénin Oluşumu. Çev. Yavuz Alagon. İstanbul: Sarmal Yay.

Akbulut, Örsan Ö. (2005). Siyaset ve Yönetim İlişkisi: Kuramsal ve Eleş̧tirel Bir Yaklaşım. Ankara: TODAİE Yay.

Akınc1, Abdulvahap ve Sefa Usta (2015). “Türkiye'de Çok-Partili Hayata Geçişte Etkili Olan İç Faktörlerin Analizi”. KMÜ Sosyal ve Ekonomik Araştırmalar Dergisi 17(29): 41-52.

Aksan, Gamze ve Özlem Çelik (2011). “Gerilim ve Uzlaşma: Demokrasi Ekseninde 
Bürokrasi ve Siyaset İlişkisi Üzerine Bir Değerlendirme”. Selçuk Üniversitesi Sosyal Bilimler Enstitüsü Dergisi 25: 1-10.

Aydemir, Şevket Süreyya (2000). İhtilalın Mantığı ve 27 Mayıs İhtilali. 7. Basım. İstanbul: Remzi Kitabevi.

Balc1, Asım (2005). "Bürokrasi-Demokrasi İlişkisi ve Hesap Verebilirlik Yaklaşımı”. Hacettepe Üniversitesi İIBF Dergisi 23(1): 313-338.

Bayram, Kemal A. ve Kerim Çınar (2007). "İktidar ve Siyasetin Gölgesinde Bürokrasi ve Demokrasi İlişkisi: İdealler, Zorunluluklar, Gerilimler”. Afyon Kocatepe Üniversitesi Sosyal Bilimler Dergisi 9(1): 11-24.

Behn, Robert D. (2001). Rethinking Democratic Accountability. Washington: Brooking Institution Press.

Bilgin, Vedat (1997). “Türkiye'de Anti Demokratik Geleneğin Gücü Nereden Geliyor?". Yeni Türkiye 3(17): 26-28.

Çavdar, Tevfik (2004). Türkiyénin Demokrasi Tarihi (1950-1995). Ankara: İmge Kitabevi.

Dahl, Robert A. (2001). Demokrasi Üstüne. Çev. Betül Kadıŏlu. Ankara: Phoenix Yay.

Demir, Fatih (2011). "Bürokrasi-Demokrasi İlişkisi ve Bürokratların Seçilmişlerce Kontrolü Sorunu”. Yönetim ve Ekonomi Dergisi 18(2): 63-84.

Dreyfus, Françoise (2014). Bürokrasinin İcadr: Fransa, Büyük Britanya ve ABD'de Devlete Hizmet Etmek. 2. Baskı. Çev. Işık Ergüden. İstanbul: İletişim Yay.

Duman, Doğan ve Serçin Sun İpekşen (2013). "Türkiyede Genel Seçim Kampanyaları". Turkish Studies 8(7): 117-135.

Durgun, Şenol (1997). “Tamamlanmamış Bir Proje: Modernleşme ya da Demokratikleşmenin Önündeki Engeller”. Yeni Türkiye 3(17): 41-48.

Dursun, Davut (2001). 27 Mayıs Darbesi. İstanbul: Şehir Yay.

Dursun, Davut (1999). Demokratikleşemeyen Türkiye. İstanbul: İşaret Yay.

Dursun, Davut (2006). Siyaset Bilimi. 3. Baskı. İstanbul: Beta Yay.

Erdoğan, Mustafa (1997). "Türkiye'de Siyasal Sistem ve Demokrasi”. Yeni Türkiye 3(17): 49-64.

Eriş, Metin (1997). "Demokrasi ve Türkiye'deki Varlığı Üzerine Bir Deneme”. Yeni Türkiye 3(17): 657-669.

Eroğul, Cem (1970). Demokrat Parti (Tarihi ve İdeolojisi). Ankara: Ankara Üniversitesi SBF Yay.

Ertan, Temuçin F. (2012). "Atatürk’ün Demokrasi Anlayışı Üzerine Bir Değerlendirme”. Genelkurmay Personel Daire Başkanliğg Askeri Tarih ve Stratejik Etüt Daire Başkanlığı Yayınları. Ankara: 1-9.

Eryılmaz, Bilal ve Hale Biricikoğlu (2011). "Kamu Yönetiminde Hesap Verebilirlik ve Etik”. İs Ablakı Dergisi 4(7): 19-45.

Eryılmaz, Bilal (2010). Bürokrasi ve Siyaset: Bürokratik Devletten Etkin Yönetime. 4. Baskı. İstanbul: Alfa Yay.

Eryiğit, Burak Hamza ve Fuat Yörükoğlu (2012). "Modernleşme Süreçlerinde De- 
mokrasi ve Bürokrasi İkilemi ve Kavramlarının Anlamsal Boyutları Üzerine Bir İnceleme”. Akademik Bakış Dergisi 32: 1-18.

Gormley, William T. ve Steven J. Bella (2012). Bureaucracy and Democracy: Accountability and Performance. $3^{\text {rd }}$ Edition. Washington: Sage Publications.

Göküş, Mehmet (2003). "Demokrat Parti Döneminde Türk Kamu Bürokrasinin Genel Görünümü”. SÜ İIBF Sosyal ve Ekonomik Araştırmalar Dergisi 5: 40-62.

Göküş, Mehmet (2000). "Tek-Parti Döneminde Türk Kamu Bürokrasisinin Gelişimi”. Amme İdaresi Dergisi 33(2): 23-33.

Göle, Nilüfer (1998). Mühendisler ve İdeoloji: Öncü Devrimcilerden Yenilikçi Seçkinlere. 2. Basım, İstanbul: İletişim Yay.

Hanioğlu, M. Şükrü (1989). "Tanzimat Bürokrasisine Dönüş Arzuları ve Jön Türkler”. Türkiye Günlüğü Say1: 8.

Heper, Metin (1974). Bürokratik Yönetim Geleneği. Ankara: ODTÜ İdari İlimler Fakültesi Yay.

Heper, Metin (1973a). Modernleşme ve Bürokrasi: Karşılaştırmalı Kamu Yönetimine Giriş. Ankara: Sosyal Bilimler Derneği Yay.

Heper, Metin (1973b). "Osmanl1-Türk Devletinde Bürokrasinin Siyasal Rolü: Kamu Yönetimi Kuramı Açısından Bazı Gözlemler”. Amme İdaresi Dergisi 6(2): 2940.

Heper, Metin (1990). “Osmanlı Devlet Geleneği”. Türkiye Günlü̆̈̈̈. Sayı: 13.

Heper, Metin (1985). The State Tradition In Turkey. Walkington: Eothen Press.

Heper, Metin (1977). Türk Kamu Bürokrasisinde Gelenekçilik ve Modernleşme. İstanbul: Boğaziçi Üniversitesi Yay.

Karatepe, Şükrü (2001). Tek Parti Dönemi. 3. Baskı, İstanbul: İz Yay.

Karpat, Kemal H. (1996). Türk Demokrasi Tarihi: Sosyal, Ekonomik, Kültürel Temeller. İstanbul: Afa Yay.

Koçak, Levent (2001). “Türk Demokrasisinde Ordu-Siyaset İlişkileri ve Askeri Müdahaleler”. Demokrasi Sorunu ve Türk Demokrasisi. Ed. D. Dursun. İstanbul: Şehir Yay. 134-152.

Köker, Levent (2005). Modernleşme, Kemalizm ve Demokrasi. 9. Baskı. İstanbul: İletişim Yay.

Köktaş, Arif (2001). “Türkiye'de Demokrasinin Gelişmesine Kısa Bir Bakış”. Demokrasi Sorunu ve Türk Demokrasisi. Ed. D. Dursun. İstanbul: Şehir Yay. 121133.

Lewis, Bernard (2007). Demokrasinin Türkiye Serüveni. Çev. Hamdi Aydoğan ve Esra Ermert. 3. Baskı. İstanbul: Yapı Kredi Yay.

Lewis, Bernard (1998). Modern Türkiyénin Doğuşu. Çev. Metin Kıratlı. 7. Baskı. Ankara: Türk Tarih Kurumu Yay.

Lijphart, Arend (1986). Çă̆daş Demokrasiler. Çev. Ergun Özbudun ve Ersin Onulduran. Ankara: Yetkin Yay.

Mises, Ludwing Von (2000). Bürokrasi. Çev. Feridun Ergin. 2. Baskı. Ankara: Liberte Yay. 
Oktay, Cemil (1997). Siyasal Sistem ve Bürokrasi: Yükselen İstemler Karşısında Türk Siyasal Sistemi ve Kamu Bürokrasisi. İstanbul: Der Yay.

Öz, Esat (1992). Türkiye'de Tek Parti Yönetimi ve Siyasal Katılma (1923-1945). Ankara: Gündoğan Yay.

Özbudun, Ergun (2003). Çağdaş Türk Politikası: Demokratik Pekişmenin Önündeki Engeller. İstanbul: Doğan Kitap Yay.

Özbudun, Ergun (1995). “Türkiye'de Devlet Seçkinleri ve Demokratik Siyasal Kültür”. Türkiye’de Demokratik Siyasal Kültür. Ed. E. Özbudun, E. Kalaycioğlu, L. Köker. Ankara: Türk Demokrasi Vakfi Yay. 16-30.

Öztürk, Namık Kemal (2003). Bürokrasinin Gücü ve Siyaset. Ankara: Siyasal Kitabevi.

Parla, Taha (1993). Ziya Gökalp, Kemalizm ve Türkiye'de Korporatizm. İstanbul: İletişim Yay.

Peters, B. Guy (2010). "Bureaucracy and Democracy”. Public Organization Review 10(3): 209-222.

Riggs, Fred W. (1971). "Bürokratlar ve Siyasal Gelişme: Çelişmeli Bir Görüş”. Çev. Selçuk Yalçındağ. Amme İdaresi Dergisi 4(2): 64-95.

Sartori, Giovanni (1993). Demokrasi Teorisine Geri Dönüş. Çev. Tunçer Karamustafaoğlu ve Mehmet Turhan. Ankara: Yetkin Yay.

Şavkılı, Cengiz ve Tülay Aydın (2013). "Atatürk Döneminde Bürokrasinin Yeniden Yapılandırılması”. Atatürk Araştırma Merkezi Dergisi 29(87): 67-90.

Şaylan, Gencay (1983). "Cumhuriyet Bürokrasisi”. Cumhuriyet Dönemi Türkiye Ansiklopedisi. Cilt 2. İstanbul: İletişim Yay.

Schmidt, Manfred G. (2002). Demokrasi Kuramlarına Girişs. Çev. M. Emin Köktaş. 2. Bask1. Ankara: Vadi Yay.

Shils, Edward (1960). "Political Development in the New States", Comparative Studies in Society and History 2(3): 265-292.

Taşkıran, Cemalettin (1994). "Atatürk Döneminde Demokrasi Denemeleri (19251930)”. Ankara Üniversitesi Türk Inkılap Tarihi Enstitüsü Atatürk Yolu Dergisi. 14: 255-265.

Tataroğlu, Muhittin (1997). "Bürokrasi ve Demokrasi İlişkisinde Temsili Bürokrasi Kavramı”. Yeni Türkiye 3(17): 563-570.

Timur, Taner (2003). Türkiye'de Çok-Partili Hayata Geçiş. 3. Baskı. Ankara: İmge Kitabevi.

Tunçkanat, Haydar (1996). 27 Mayıs 1960 Devrimi. İstanbul: Çağdaş Yay.

Tutum, Cahit (1972). Türkiye'de Memur Güvenliği. Ankara: TODAİE Yay.

Weber, Max (2005). Bürokrasi ve Otorite. Çev. H. Bahadır Akın. Ankara: Adres Yay.

Weber, Max (2004). Sosyoloji Yazıları. Çev. Taha Parla. 6.Baskı, İstanbul: İletişim Yay.

Yılmaz, Aytekin (1997). "Demokratik Gelişme ve Türkiye'de Demokrasi”. Yeni Türkiye 3(17): 519-539. 


\title{
The Role of Bureaucracy in Turkey's Democratization Process: One-Party Period and Transition to Multi-Party System *
}

\author{
Harun Kırlmaz ${ }^{* *}$
}

\begin{abstract}
This study aims to scrutinize the role, function and the attitude of the bureaucracy in the process of democratization. In this context, this historical study examining the process of democratization in Turkey from the proclamation of the republic to the transition to a multiparty system briefly discusses the relationship between bureaucracy and democracy from a theoretical perspective. Afterwards, the formation of a bureaucratic management tradition, which has an important place in Turkish political life, has been mentioned in this historical research, which has a significant place in Turkish political life, has been addressed. The role of the bureaucracy in the process of democratization during the one-party period and the change that has occurred in this process with the transition to a multi-party system were subsequently examined. In conclusion, in the Turkish context it is observed that there is a dilemma between bureaucracy and democracy, the bureaucracy had negatively affected the process of democratization, it was more effective in one-party period, and the power of bureaucracy was relatively weakened with the transition to a multi-party system. Yet, the tradition of bureaucratic tutelage has lasted its effects to this day and this situation harm the process of democratization.
\end{abstract}

\section{Keywords}

Bureaucracy, democratization, Turkey, one-party period, multi-party system.

\footnotetext{
Date of Arrival: 02 August 2017 - Date of Acceptance: 15 August 2017

You can refer to this article as follows:

Kırılmaz, Harun (2020). “Türkiye’nin Demokratikleşme Sürecinde Bürokrasinin Rolü: Tek-Parti Dönemi ve Çok-Partili Sisteme Geçiş”. bilig - Journal of Social Sciences of the Turkic World 92: 1-28.

** Assoc. Prof. Dr., Sakarya University, Business School, Health Administration Department - Sakarya/ Turkey

ORCID ID: orcid.org/0000-0001-6055-6826

hkirilmaz@sakarya.edu.tr
} 


\title{
Роль бюрократии в демократизации Турции: период однопартийности и переход к многопартийной системе*
}

\author{
Харун Кырылмаз ${ }^{* *}$
}

\begin{abstract}
Аннотация
Цель данного исследования - изучить роль, функцию бюрократии в демократизации и ее отношение к этому процессу. В связи с этим в этом историческом исследовании, посвященном изучению процесса демократизации в Турции от провозглашения республики до перехода к многопартийной системе, с теоретической точки зрения кратко рассматриваются отношения между бюрократией и демократией. Вслед за этим исследовано формирование бюрократической традиции управления, занимающей важное место в политической жизни Турции, а также роль бюрократии в процессе демократизации в однопартийный период и изменения, которые произошли в этом процессе с переходом к многопартийной системе. В заключении показано, что в турецком контексте наблюдается дилемма между бюрократией и демократией, бюрократия негативно повлияла на процесс демократизации, она была более эффективной в однопартийный период, а власть бюрократии была относительно ослаблена с переходом к многопартийности. Тем не менее, традиция бюрократической опеки сохранилась до наших дней, и эта ситуация наносит ущерб процессу демократизации.
\end{abstract}

\section{Ключевые слова}

Бюрократия, демократизация, Турция, однопартийный период, многопартийная система.

\footnotetext{
" Поступило в редакцию: 02 августа 2017 г. - Принято в номер: 15 августа 2017 г.

Ссылка на статью:

Kırılmaz, Harun (2020). "Türkiye'nin Demokratikleșme Sürecinde Bürokrasinin Rolü: Tek-Parti Dönemi ve Çok-Partili Sisteme Geçiş”. bilig - Журнал Гуманитарных Наук Тюркского Мира 92: 1-28.

** Доц., д-р, Университет Сакарьи, Факультет менеджмента, кафедра управления здравоохранением - Сакарья / Турция ORCID ID: orcid.org/0000-0001-6055-6826 hkirilmaz@sakarya.edu.tr
} 